\title{
BIOPESTICIDE APPLICATION ON KINNOW MANDARIN (CITRUS RETICULATA BLANCO) WITH IMPROVED PRUNING CAN ENHANCE COSMETIC AND PHYSICAL CHARACTERS IN FRUIT
}

\author{
AFTAB, M. ${ }^{1}-$ KHAN, M. A. ${ }^{*}-$ HABIB, U. $^{1}-$ AHMAD, M. $^{2}$ \\ ${ }^{1}$ Deparment of Horticulture, PMAS-Arid Agriculture University, Rawalpindi 46300, Pakistan \\ ${ }^{2}$ Department of Entomology, PMAS-Arid Agriculture University, Rawalpindi 46300, Pakistan \\ *Corresponding author \\ email:drazam1980@uaar.edu.pk
}

(Received $4^{\text {th }}$ Jul 2021; accepted $30^{\text {th }}$ Sep 2021)

\begin{abstract}
Kinnow mandarin (Citrus reticulata Blanco) is a highly valued fruit crop with ever increasing demand in national and international markets. Farmers eagerly put their efforts to produce quality fruit even compromising food safety, which is a preliminary concern of every consumer due to increased awareness of the adverse impact of pesticide abuses in conventional farming system. Use of environment friendly non-hazardous biological agents is increasing particularly for perishable horticultural crops. The project was designed to evaluate ecofriendly approaches to improve plant vigor and fruit quality of Kinnow mandarin replacing unsafe synthetic pesticides. During first two years of trial (2014 and 2015) improved pruning practices (traditional, $10 \%$ and 20\%) and biopesticides (neem oil and lemongrass oil each at $1.5 \%$ ) were evaluated separately while in third year (2016) integrated treatment applications were designed to investigate cumulative effect of pruning and biopesticides on fruit quality in comparison with control and sole application of Bifenthrin at $2 \mathrm{ml} / \mathrm{L}$. Cosmetic, physical and biochemical attributes were studied in fully ripened fruits. Initial experiments witnessed significant reduction in fruit blemishes with $20 \%$ pruning and $1.5 \%$ neem oil treatment with improved physical quality, while cumulative application resulted in prominent statistically significant improvement. Tree pruning along with foliar spray of neem oil significantly improved fruit physical quality and cosmetic appearance.
\end{abstract}

Keywords: blemishes, fruit quality, neem oil, lemongrass oil, canopy management, non-hazardous, ecofriendly

\section{Introduction}

Kinnow mandarin is the most prominent member of the citrus family particularly for juices and fresh consumption. Like any other commercial fruit crop quality is considered as driving force in supply chain for both Pakistan and international destinations (Dandekar, 2004). Determinants of fruit quality can be divided into factors affecting external quality and factors defining internal quality. Both are of critical importance, since external quality influences initial purchasing decision, while internal quality determines consumption and successive purchase (Chaparro, 2004). Cosmetic or external fruit quality deteriorates by several abiotic (wind, physical damage, physiological disorders) and biotic factors, including insects (thrips, mites, red scale, peel miner, fruit fly and others) and diseases (citrus scab, citrus melanose and citrus canker) which damage cuticle and epidermal cells of newly developed fruit (Fatima and Iram, 2019), while table quality of fruits is influenced by different biochemical factors such as TSS/TA ratio, $\mathrm{pH}$, acidity and sugar profile (Ahmed, 2005).

Synthetic pesticides are aggressively used to reduce pathogen load on crops in agricultural industry. Excessive use of these pesticides is injurious as they are highly 
toxic, non-biodegradable and possess residual impact. Exposure to pesticides poses a continuous health hazard, especially in the agricultural working environment (Yadav et al., 2015). Within this context, pesticide use has raised serious concerns not only due to potential effects on human health, but also about impacts on wildlife and sensitive ecosystems (Ibitayo, 2006). Modern ecofriendly approaches discourage the use of chemicals all over the world (Chaudhary et al., 2017). Production of fresh produce with minimum pesticide residual levels has become a big challenge for the industry as most of the countries are demanding maximum residual limits (MRLs) report with every consignment (Khalid et al., 2012).

As an alternative and non-hazardous approach, many plant-based oils are reported to possess a broad spectrum of activity against insect pests and fungal pathogens (Hikal et al., 2017). These are generally termed as biopesticides. These biopesticides are reported to have insecticidal, antifeedant, repellent, oviposition, deterrent, growth regulatory and anti-vector activities (Dimetry et al., 2018). Recent investigations indicate that some chemical constituents of these oils interfere with the nervous system in insects. As the target site is not shared with mammals, most essential oil chemicals are relatively nontoxic to mammals and fish, meeting the criteria for "reduced risk" pesticides (Chaudhary et al., 2017). Thus, in the present concept of green pesticides, some rational attempts have been made to include substances such as plant extracts, hormones, pheromones (Koul, 2008). A number of source plants have been traditionally used for protection of stored commodities, but interest in the biopesticides is reintroduced due to their fumigant, repellent and contact insecticidal activities to a wide range of pests in field conditions (Priestley et al., 2003).

Along with some others, neem oil is widely known to use as a safe pest management technique. Studies witnessed that neem oil proved as a good substitute of synthetic insecticides to manage citrus insect pest like leaf miner (Arshad et al., 2019; Deka et al., 2018). Neem seeds contain numerous azadirachtin analogs which are well known as a potent antifeedant to many insects (Sirohi and Tandon, 2014). Azadiractin based products are recommended in the control of insects such as aphids, armyworms, caterpillars, beetles, borers, budworms, cutworms, leafhoppers, leaf miners, lepidopterous larvae, loopers, maggots, mealy bugs, psyllids, scale, stink bugs, weevils and whiteflies (Dayan et al., 2009). Several other plant extracts and essential oils are in general practice as repellents like lemongrass, marigold and basil. Some of the plant extracts especially leaf extract of chrysanthemum naturally contain pyrethrum and can be used as pesticide against many sucking pests.

Along with ecofriendly chemicals, orchard management and cultural practices are the key factor contributing to the quality of horticultural produce. Poor cultural practices can seriously impact fruit quality. Pruning is a valuable practice in citrus orchard suffering from negligence or decline to induce rejuvenation and enhance vegetative growth (Rani et al., 2018). In combination with regular schedule of pest control, removal of decadent wood will improve top root balance, resulting good quality fruit (Morales and Davies, 2000). Pruning in citrus is considered as a cheap and efficient practice to avoid physical damage like bruising of the fruit from rubbing with branches as reduction in crowded tree canopy decreases the risk of wind born blemishes. It also increases the light penetration in the tree, improves general health and vigor of the tree meanwhile pruning diseased and week branches also reduced the risk of fungal infestation (Dick, 2007; Marini, 2014). Pruning is done as a regular practice to reduce disease load and to improve light penetration to attain better fruit quality in many 
countries like USA (Fake, 2012). Pruning practices were never tested or standardized in Pakistan as a strategy to minimize fruit blemishes in Kinnow mandarin.

Putting all these factors under consideration, current study was designed to improve cosmetic, physical and biochemical aspects in Kinnow mandarin with application of non-hazardous biopesticides coupled with improved tree pruning practices in order to provide an alternative approach to cast off synthetic pesticides intensively used by citrus growers in Pakistan.

\section{Materials and methods}

Three-year study was conducted at commercial Kinnow mandarin (Citrus reticulata) orchard in prominent citrus growing District Sargodha of Punjab Province, Pakistan $\left(32^{\circ} 05^{\prime} \mathrm{N} 72^{\circ} 40^{\prime} \mathrm{E}\right)$. Uniformly aged Kinnow mandarin trees, managed under similar cultural practices with same productivity potential, history and symptoms of identified potential issues were selected to perform the experiment.

During 2014 and 2015, impact of improved tree pruning practices and biopesticides applications were tested separately. The treatments included control $\left(\mathrm{T}_{1}\right)$, traditional pruning (Removal of dried and intermingled branched) $\left(\mathrm{T}_{2}\right), 10 \%$ pruning (removing additional $10 \%$ biomass) $\left(\mathrm{T}_{3}\right), 20 \%$ pruning (removing additional $20 \%$ biomass) $\left(\mathrm{T}_{4}\right)$, $1.5 \%$ neem oil $\left(\mathrm{T}_{5}\right), 1.5 \%$ lemongrass oil $\left(\mathrm{T}_{6}\right)$ and $2 \mathrm{ml} / \mathrm{L}$ bifenthrin $\left(\mathrm{T}_{7}\right)$, where bifenthrin was applied for comparison as it is one of the most widely used pesticides to overcome pest problems in citrus production. While in 2016, combinations of best performing treatments were tested in comparison with control and synthetic insecticides. The treatment combinations included control $\left(\mathrm{T}_{1}\right), 10 \%$ pruning (removing additional $10 \%$ biomass) $* 1.5 \%$ neem oil $\left(\mathrm{T}_{2}\right), 20 \%$ pruning (removing additional $20 \%$ biomass) $* 1.5 \%$ neem oil $\left(\mathrm{T}_{3}\right)$ and bifenthrin at $2 \mathrm{ml} / \mathrm{L}\left(\mathrm{T}_{4}\right)$. Selected trees were pruned at the end of February according to the treatment plan. Spray applications were carried out at three different developmental stages i.e. before flowering, at fruit set (when more than $90 \%$ petal fall reached) and at pea size fruit.

At commercial maturity, data regarding nature and extent of blemishes (fruit cosmetic quality) were recorded for randomly selected 100 fruits from each replicated tree. Data on nature of blemishes was divided into biotic and abiotic categories, among biotic factors, percent insect pest infected fruit (thrips, scales and mites) and percent disease infected fruits (scab, melanose and canker) were observed while among abiotic factors percent infected fruits due to wind scars, stem injury and styler end deformity (SED) were observed. Fruit was categorized for skin blemishes as described by Khalid et al. (2012).

Physical quality parameters included, fruit diameter, fruit weight, juice weight, peel thickness and number of seeds per fruit. Fruit diameter and peel thickness was recorded with the help of digital vernier caliper, while fruit and juice weight were recorded with weighing scale. The biochemical characters including ascorbic acid, $\mathrm{pH}$, total soluble solids/titratable acidity (TSS/TA) ratio and total sugar were determined according to standard techniques, as described by Saleem et al. (2008) and Khan et al. (2011).

Experiment was laid out under randomized complete block design (RCBD) with three replications having one tree per replicate. Data regarding parameters was compared by HSD test with 5\% significance level by using Statistix 8.1 (Steel et al., 1997). 


\section{Results and discussion}

\section{Fruit cosmetic quality}

To assess cosmetic quality fruits were analyzed for nature and extent of blemishes. Among nature of blemishes, fruits were expressed as percent infected fruits and categorized as insect pest induced (thrips, scales and mites), disease induced (scab, melanose and canker) and a biotic induced (wind scars, stem injury and SED) fruit blemishes against tree pruning and biopesticides as presented in Figures 1 and 2.

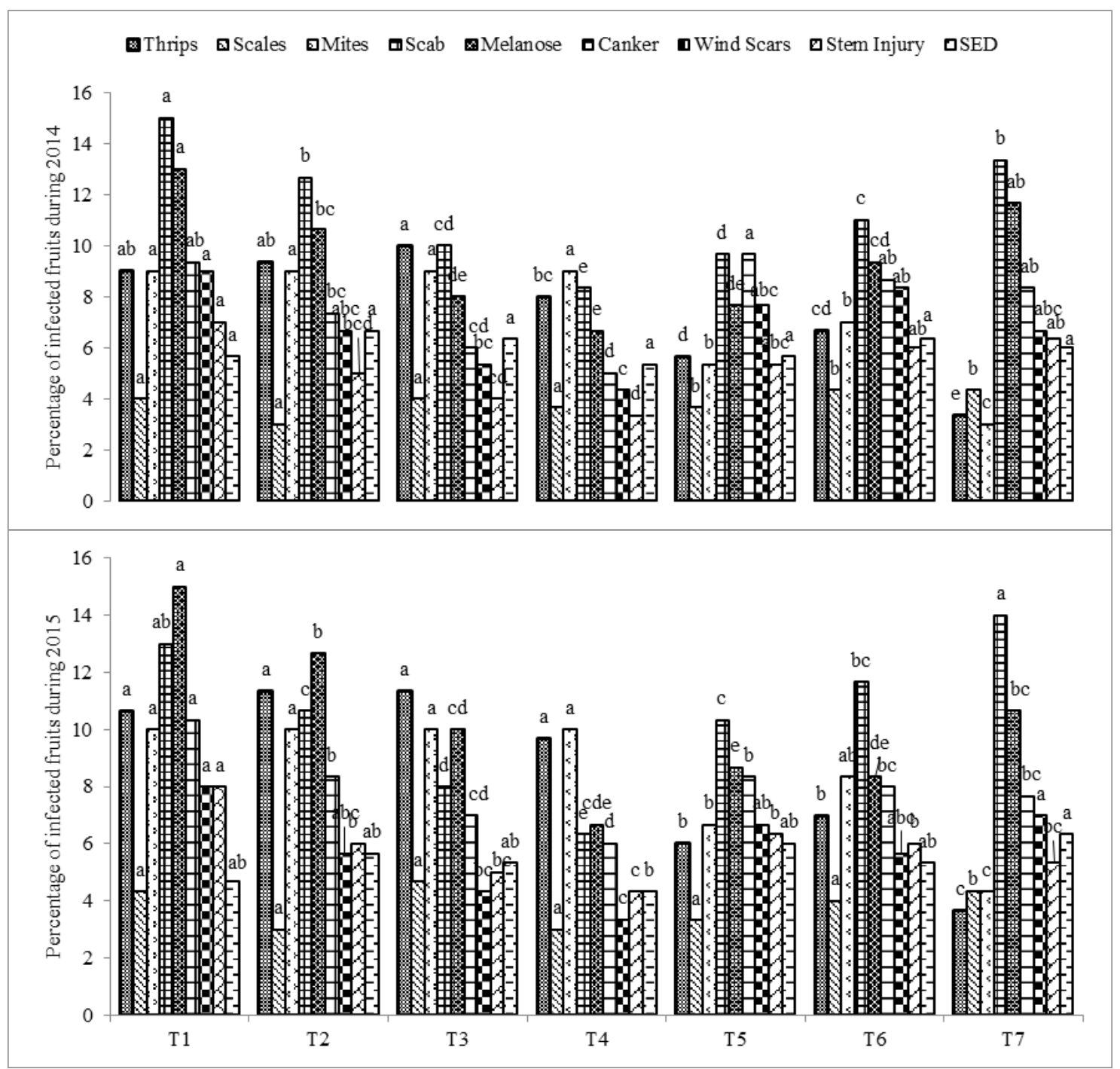

Figure 1. Effect of biopesticides and tree pruning on nature of fruit blemishes during two consecutive years (2014 and 2015). $T 1=$ Control, $T 2=$ Traditional Pruning, T3 = pruning $10 \%$ T4 $=$ Pruning 20\%, T5 = Neem oil 1.5\%, T6 = Lemongrass oil 1.5\%, T7 = Bifenthrin $2 \mathrm{ml} / \mathrm{L}$

During 2014 and 2015 studies revealed that tree pruning at 20\% alone proved beneficial to control blemishes on fruit skin due to fungus (scab $8.33 \%$ and $6.33 \%$, melanose $6.67 \%$ and $6.67 \%$ and canker $5 \%$ and $6 \%$ ), wind $(4.33 \%$ and $3.33 \%$ ) and stem injury $(3.33 \%$ and $4.33 \%)$ as compared to other treatments, while tree pruning did not put any substantial impact on insect pest induced fruit blemishes. Biopesticides 
especially neem oil at $1.5 \%$ significantly reduced incidence of thrips (5.67 and 6\%) and mites (5.33 and 6.67\%) induced fruit blemishes as compared to other treatments while remained at par with synthetic insecticide i.e. Bifenthrin at $2 \mathrm{ml} / \mathrm{L}$ (thrips $3.33 \%$ and $3.67 \%$ and mites $3 \%$ and $4.33 \%$ ). Chemical agent (Bifenthrin at $2 \mathrm{ml} / \mathrm{L}$ ) failed to control fungal induced blemishes, however it provided most efficient control over insect pest induced blemishes on fruit skin in Kinnow mandarin. Fruit blemishes due to styler end deformity exhibited non-significant trend among all treatments.

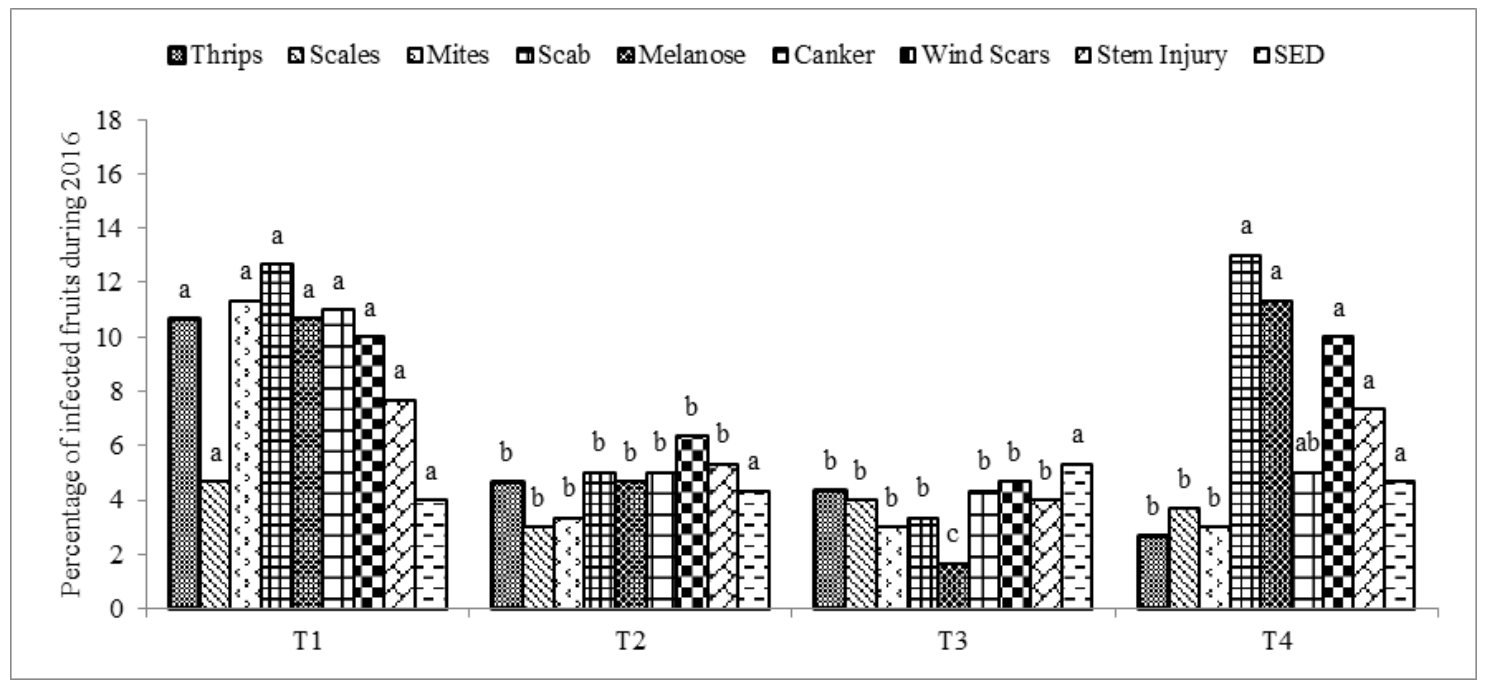

Figure 2. Effect of biopesticides and tree pruning on nature of fruit blemishes during 2016. $T_{1}=$ Control, $T_{2}=$ Pruning $10 \%+$ Neem oil $1.5 \%, T_{3}=$ Pruning $20 \%+$ Neem oil $1.5 \%$, $T_{4}=$ Bifenthrin $2 \mathrm{ml} / \mathrm{L}$

While taking into account data collected in 2016, combination of pruning and neem oil significantly reduced abiotic and disease induced fruit blemishes. Maximum reduction in fruit blemishes due to scab (3.33\%), melanose (1.67\%), canker $(4.33 \%)$, wind scars (4.67\%) and stem injury (4\%) were observed in plants pruned at $20 \%$ and sprayed with $1.5 \%$ neem. Among insect pest induced fruit blemishes again Bifenthrin proved to be most effective treatment (thrips: $2.67 \%$, mites: $3 \%$ ) as compared to other treatments.

Among extent of blemishes, fruits were categorized into six different grades having $<1 \%, 1-5 \%, 6-10 \%, 11-25 \%, 26-50 \%$ and $>50 \%$ blemished surface area against application of different treatments which reflected significant difference as shown in Figures 3 and 4. During 2014 and 2015, maximum number of fruit with less than $1 \%$ (29 and 26.67\%), 1-5\% (31.67 and 34\%) and 6-10\% (20.67 and 23\%) blemished area were obtained from $2 \mathrm{ml} / \mathrm{L}$ bifenthrin treated Kinnow mandarin plants followed by $1.5 \%$ neem oil application for less than $1 \%$ (21.67 and 22.67\%), 1-5\% (30.33 and 30\%) and $6-10 \%$ (20.33 and $21 \%$ ) blemished area and pruning at $20 \%$ for less than $1 \%(21.67$ and $23.67 \%$ ), $1-5 \%$ (26 and 24.67\%) and 6-10\% (18.33 and 20.33\%) blemished area as both were statistically at par with each other.

In 2016, when tree pruning was coupled with neem oil application, maximum number of fruits with less than $1 \%(28.67 \%), 1-5 \%(35.67 \%)$ and $6-10 \%(24.67 \%)$ blemished area was obtained from $20 \%$ pruning in combination with $1.5 \%$ neem oil application. 


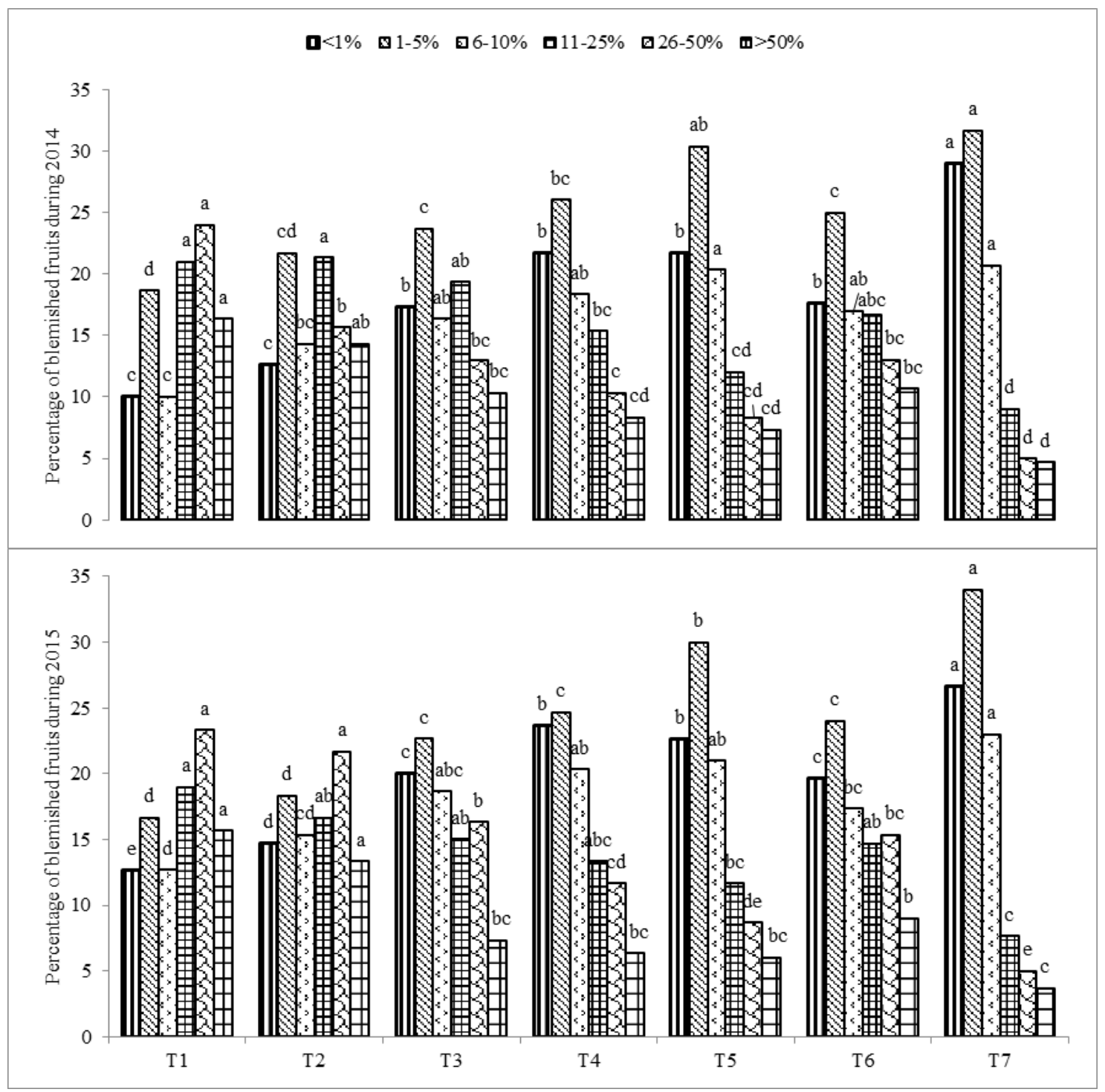

Figure 3. Effect of biopesticides and tree pruning on extent of fruit blemishes during two consecutive years (2014 and 2015). $T_{1}=$ Control, $T_{2}=$ Traditional Pruning, $T_{3}=$ pruning $10 \%$ $T_{4}=$ Pruning $20 \%, T_{5}=$ Neem oil 1.5\%, $T_{6}=$ Lemongrass oil 1.5\%, $T_{7}=$ Bifenthrin $2 \mathrm{ml} / \mathrm{L}$

Study revealed that pruning posed significant impact on disease born and wind born blemishes and when coupled with neem oil application insect pest born blemishes were also managed even more efficiently as compared to sole application of neem oil as shown in Figure 5. Pruning open up the canopy and improves pest control by allowing better spray penetration into the tree, hence while combined application of pruning and neem oil suppressed insect pest induced blemishes more efficiently (Khalid et al., 2012). While carrying out pruning most of diseased branches were removed which lower down fungal inoculums in the tree and uplift emergence and growth of healthy shoots (Rani et al. 2018), resulting aeration of tree canopy, reduced canopy moisture and suppressed the chance of fungal infestation and severity of many diseases (Marini, 2014).

The effect of neem oil on thrips, scales, mites, scab, melanose and canker induced fruit blemishes was statistically significant however, wind scars, stem injury and styler end deformation did not show significant response against neem oil application. It has 
been observed that various biopesticides can effectively be used to control different insects and diseases of fruits (Pavela and Benelli, 2016). Biopesticides have certain active chemicals which act as anti-fungal or insecticides (Hikal et al., 2017) to control pathogen and insects induced biotic stresses during pre-harvest stage of fruits (Hong et al., 2015). In the same way, neem essential oils were also known for their varied pest management characteristics (Koul et al., 2003).

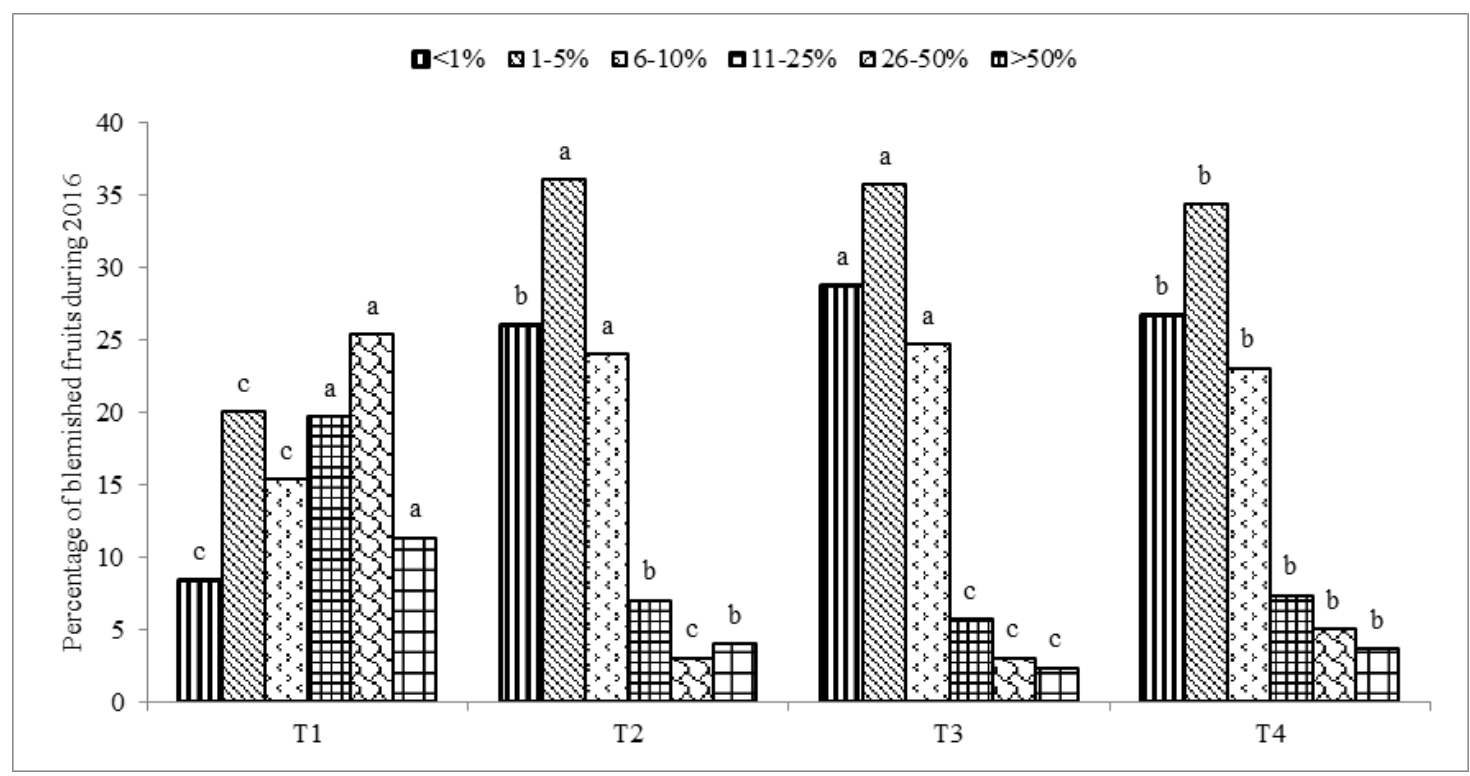

Figure 4. Effect of biopesticides and tree pruning on extent of fruit blemishes during 2016. $T_{1}=$ Control, $T_{2}=$ Pruning $10 \%+$ Neem oil 1.5\%, $T_{3}=$ Pruning $20 \%+$ Neem oil $1.5 \%$,

\section{$T_{4}=$ Bifenthrin $2 \mathrm{ml} / \mathrm{L}$}
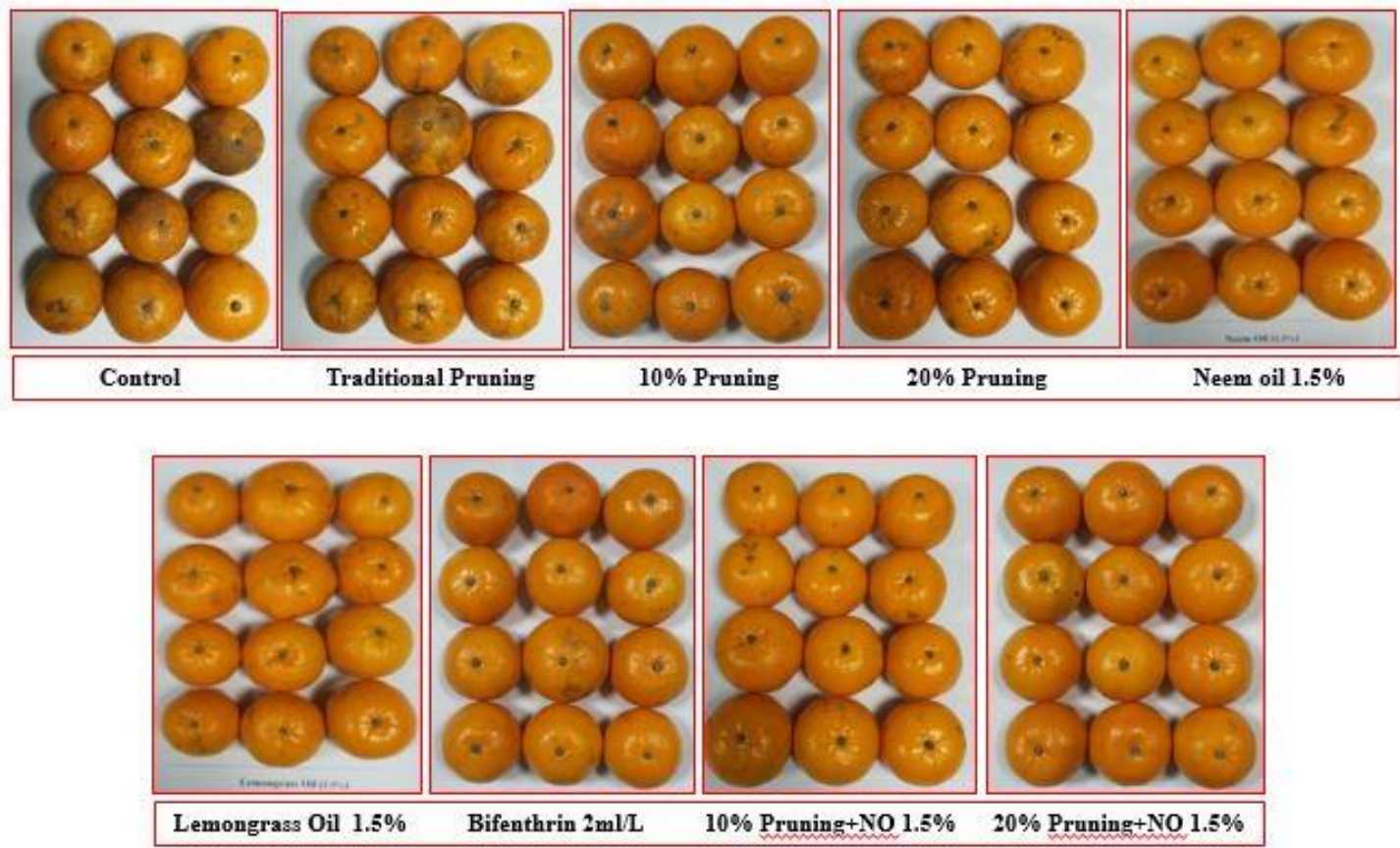

Figure 5. Cosmetic quality of Kinnow mandarin fruits in response to tree pruning and biopesticides 


\section{Fruit physical quality}

Fruits harvested from different treatments were observed for fruit diameter, fruit weight, juice weight, peel thickness and number of seeds per fruit. During the whole three years of study, tree pruning and biopesticides significantly improved fruit diameter as shown in Figure 6, fruit weight and juice weight but did not pose any substantial impact on number of seeds per fruit and peel thickness except during 2014, where peel thickness was observed maximum in $10 \%$ pruned trees and minimum in $2 \mathrm{ml} / \mathrm{L}$ Bifenthrin treated trees as shown in Tables 1 and 2.

During 2014 and 2015, 10\% pruning resulted in maximum fruit diameter $(76.82 \mathrm{~mm}$ and $75.87 \mathrm{~mm}$ ), fruit weight (184.76 $\mathrm{g}$ and $181.71 \mathrm{~g}$ ) and juice weight (44.97 $\mathrm{g}$ and $44.92 \mathrm{~g}$ ) while in 2016 when pruning was combined with neem oil application again $10 \%$ pruning sprayed with $1.5 \%$ neem oil resulted in maximum fruit diameter $(74.65 \mathrm{~mm})$, fruit weight $(178.36 \mathrm{~g})$ and juice weight $(47.43 \%)$ followed by $20 \%$ pruning sprayed with $1.5 \%$ neem oil for fruit diameter $(73.63 \mathrm{~mm})$, fruit weight $(175.91 \mathrm{~g})$ and juice weight $(45.5 \%)$ and minimum in control (fruit diameter: $68.51 \mathrm{~mm}$, fruit weight: $167.03 \mathrm{~g}$, juice weight: $44.45 \%$ ).

Pruning is an important orchard practice because pruning can influence fruit quality by creating balance between vegetative growth and fruiting. Annual pruning always enhances fruit quality. Pruning increases fruit size because excessive flower buds are removed and pruning encourages the growth of new shoots with high-quality flower buds. Pruning improves light penetration into the canopy, and light is required for flower bud development, photosynthesis and growth (Marini, 2014).

The importance of sunlight intercepted by the tree canopy in the production of high yield of good quality fruit cannot be over emphasized. Light becomes a limiting factor in crowded groves and pruning improves light access. Ahmad et al. (2006) studied the effect of pruning on the yield and quality of Kinnow fruit and conclusively found that pruning appeared to be the best method to obtain maximum yield, quality, fruit size, weight and juice in Kinnow fruit. Pruning increased the percentage of large fruit and reduced the percentage of small fruit (Morales and Davies, 2000).

Table 1. Effect of biopesticides and tree pruning on physical fruit quality during 2014 and 2015

\begin{tabular}{|c|c|c|c|c|c|c|c|c|c|c|}
\hline \multicolumn{11}{|c|}{ Fruit physical quality } \\
\hline \multirow[t]{2}{*}{ Treatments } & \multicolumn{2}{|c|}{$\begin{array}{c}\text { Fruit diameter } \\
(\mathbf{m m})\end{array}$} & \multicolumn{2}{|c|}{$\begin{array}{c}\text { Fruit weight } \\
(\mathrm{g})\end{array}$} & \multicolumn{2}{|c|}{$\begin{array}{c}\text { Juice weight } \\
(\%)\end{array}$} & \multicolumn{2}{|c|}{\begin{tabular}{|c|} 
Peel thickness \\
$(\mathbf{m m})$
\end{tabular}} & \multicolumn{2}{|c|}{$\begin{array}{c}\text { No of seeds } \\
\text { (No) }\end{array}$} \\
\hline & 2014 & 2015 & 2014 & 2015 & 2014 & 2015 & 2014 & 2015 & 2014 & 2015 \\
\hline $\mathrm{T}_{1}$ & $68.72 c$ & $69.78 \mathrm{c}$ & $167.93 \mathrm{~d}$ & $164.88 d$ & $41.65 b$ & $42.03 b$ & $2.67 \mathrm{ab}$ & $2.52 \mathrm{a}$ & $20.7 \mathrm{a}$ & $19.27 \mathrm{a}$ \\
\hline $\mathrm{T}_{2}$ & $72.76 \mathrm{~b}$ & $71.63 b$ & $172.98 b$ & $172.93 \mathrm{c}$ & $42.63 \mathrm{ab}$ & 43.01ab & $2.63 \mathrm{ab}$ & $2.28 \mathrm{a}$ & $19.77 \mathrm{a}$ & $20.33 a$ \\
\hline $\mathrm{T}_{3}$ & $76.82 \mathrm{a}$ & $75.87 \mathrm{a}$ & $184.76 \mathrm{a}$ & $181.71 \mathrm{a}$ & & $44.92 \mathrm{a}$ & $2.85 \mathrm{a}$ & $2.67 \mathrm{a}$ & $20.2 \mathrm{a}$ & $19.17 \mathrm{a}$ \\
\hline $\mathrm{T}_{4}$ & $74.12 \mathrm{a}$ & $74.44 a$ & $180.54 \mathrm{ab}$ & $177.49 \mathrm{ab}$ & $43.09 \mathrm{ab}$ & $44.37 \mathrm{ab}$ & $2.72 \mathrm{ab}$ & $2.37 \mathrm{a}$ & $20.97 \mathrm{a}$ & $18.77 \mathrm{a}$ \\
\hline $\mathrm{T}_{5}$ & $75.68 \mathrm{a}$ & 73.61ab & $170.98 b c$ & $174.07 \mathrm{~b}$ & & $44.19 \mathrm{a}$ & $2.03 \mathrm{a}$ & $2.25 \mathrm{a}$ & $20.20 \mathrm{a}$ & $20.00 \mathrm{a}$ \\
\hline $\mathrm{T}_{6}$ & $72.82 b$ & $70.74 b$ & $170.61 \mathrm{c}$ & $173.7 \mathrm{~b}$ & $43.33 \mathrm{a}$ & $43.98 \mathrm{ab}$ & $1.91 \mathrm{~b}$ & $2.13 \mathrm{a}$ & $19.47 \mathrm{a}$ & $19.27 \mathrm{a}$ \\
\hline $\mathrm{T}_{7}$ & 76.60a & $74.53 \mathrm{a}$ & $172.42 \mathrm{bc}$ & $175.51 \mathrm{ab}$ & $44.31 \mathrm{a}$ & $44.42 \mathrm{a}$ & $1.84 \mathrm{~b}$ & $2.06 \mathrm{a}$ & $20.17 \mathrm{a}$ & $19.97 \mathrm{a}$ \\
\hline $\begin{array}{c}\operatorname{HSD}(p \leq 0.05 \\
)\end{array}$ & 2.869 & 2.683 & 2.960 & 2.960 & 2.674 & 2.592 & NS & NS & NS & NS \\
\hline
\end{tabular}

Means sharing similar letter are not significantly different according to HSD test $(P \leq 0.05)$. NS $=$ Not significant. $\mathrm{T}_{1}=$ Control, $\mathrm{T}_{2}=$ Traditional Pruning, $\mathrm{T}_{3}=$ pruning $10 \% \mathrm{~T}_{4}=$ Pruning $20 \%, \mathrm{~T}_{5}=$ Neem oil $1.5 \%, \mathrm{~T}_{6}=$ Lemongrass oil $1.5 \%, \mathrm{~T}_{7}=$ Bifenthrin $2 \mathrm{ml} / \mathrm{L}$ 


$$
-5041
$$

Table 2. Effect of biopesticides and tree pruning on physical fruit quality during 2016

\begin{tabular}{c|c|c|c|c|c}
\hline \multicolumn{6}{c}{ Fruit physical quality } \\
\hline Treatments & $\begin{array}{c}\text { Fruit diameter } \\
(\mathbf{m m})\end{array}$ & $\begin{array}{c}\text { Fruit weight } \\
(\mathbf{g})\end{array}$ & $\begin{array}{c}\text { Juice weight } \\
(\mathbf{\%})\end{array}$ & $\begin{array}{c}\text { Peel thickness } \\
(\mathbf{m m})\end{array}$ & $\begin{array}{c}\text { No of seeds } \\
(\mathbf{N o})\end{array}$ \\
\hline $\mathrm{T}_{1}$ & $68.51 \mathrm{c}$ & $167.03 \mathrm{c}$ & $44.45 \mathrm{~b}$ & $2.46 \mathrm{a}$ & $19.5 \mathrm{a}$ \\
$\mathrm{T}_{2}$ & $74.65 \mathrm{a}$ & $178.36 \mathrm{a}$ & $47.43 \mathrm{a}$ & $2.76 \mathrm{a}$ & $19.2 \mathrm{a}$ \\
$\mathrm{T}_{3}$ & $73.63 \mathrm{ab}$ & $175.91 \mathrm{ab}$ & $45.5 \mathrm{ab}$ & $2.97 \mathrm{a}$ & $19.53 \mathrm{a}$ \\
$\mathrm{T}_{4}$ & $73.45 \mathrm{~b}$ & $174.55 \mathrm{~b}$ & $45.28 \mathrm{ab}$ & $2.43 \mathrm{a}$ & $20.63 \mathrm{a}$ \\
$\mathrm{HSD}(\mathrm{p} \leq 0.05)$ & 2.34 & 13.32 & NS & NS & NS \\
\hline
\end{tabular}

Means sharing similar letter are not significantly different according to HSD test $(\mathrm{P} \leq 0.05)$. NS $=$ Not significant. $\mathrm{T}_{1}=$ Control, $\mathrm{T}_{2}=$ Pruning $10 \%+$ Neem oil $1.5 \%, \mathrm{~T}_{3}=$ Pruning $20 \%+$ Neem oil $1.5 \%$, $\mathrm{T}_{4}=$ Bifenthrin $2 \mathrm{ml} / \mathrm{L}$

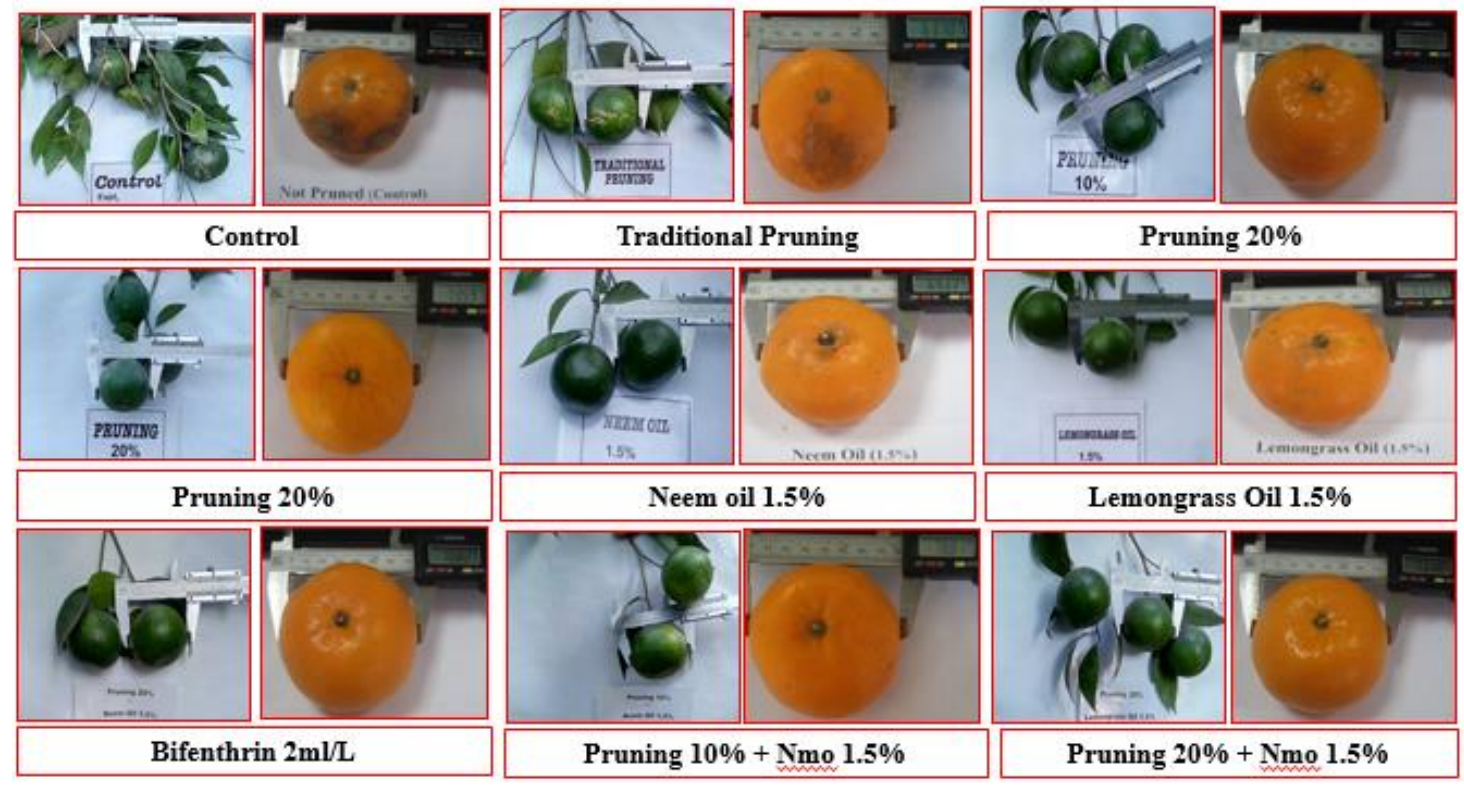

Figure 6. Pictorial description of fruit diameter influenced by tree pruning and biopesticides

\section{Fruit biochemical quality}

Fruits harvested from different treatments were analyzed for ascorbic acid, $\mathrm{pH}$, TSS/TA ratio and total sugar contents. During the whole 3 years of study, tree pruning and biopesticides did not put any substantial positive or negative impact on fruit biochemical features as shown in Tables 3 and 4.

Results indicated that pruning has non-significant changes on biochemical quality of Kinnow mandarin fruits, same trees were sprayed with neem oil as well. The results clearly indicate both pruning and biopesticides did not alter fruit quality when accessed on postharvest biochemical parameters. These management practices are useful to enhance external fruit quality without any impact on flavor, taste and sweetness in Kinnow mandarin.

Similar finding has already been reported by Ahmad et al. (2006), reporting nonsignificant response of pruning on TSS, TA and TSS/TA ratio in Kinnow mandarin 
fruit, and Khalid et al. (2012) revealing non-significant influence of pruning equipped with HMO application on Kinnow mandarin biochemical fruit quality. The application of biopesticides is known to effectively maintain higher TSS, TA and lower TSS/TA ratio during postharvest storage but not during pre-harvest situations (Sivakumar and Bautista-Banos, 2014).

Table 3. Effect of biopesticides and tree pruning on biochemical fruit quality during 2014 and 2015

\begin{tabular}{c|c|c|c|c|c|c|c|c}
\hline \multirow{2}{*}{ Treatments } & \multicolumn{2}{c}{$\begin{array}{c}\text { Vitamin C } \\
(\mathbf{m g} / \mathbf{1 0 0} \mathbf{g})\end{array}$} & \multicolumn{2}{|c|}{$\mathbf{p H}$} & \multicolumn{2}{c}{ TSS/TA } & \multicolumn{2}{c}{$\begin{array}{c}\text { Total sugars } \\
(\%)\end{array}$} \\
\cline { 2 - 9 } & $\mathbf{2 0 1 4}$ & $\mathbf{2 0 1 5}$ & $\mathbf{2 0 1 4}$ & $\mathbf{2 0 1 5}$ & $\mathbf{2 0 1 4}$ & $\mathbf{2 0 1 5}$ & $\mathbf{2 0 1 4}$ & $\mathbf{2 0 1 5}$ \\
\hline $\mathrm{T}_{1}$ & $29.12 \mathrm{a}$ & $29.8 \mathrm{a}$ & $4.13 \mathrm{a}$ & $4.09 \mathrm{a}$ & $11.39 \mathrm{a}$ & $10.55 \mathrm{a}$ & $6.95 \mathrm{a}$ & $7.31 \mathrm{a}$ \\
$\mathrm{T}_{2}$ & $31.11 \mathrm{a}$ & $31.6 \mathrm{a}$ & $2.28 \mathrm{a}$ & $4.22 \mathrm{a}$ & $12.01 \mathrm{a}$ & $10.66 \mathrm{a}$ & $6.79 \mathrm{a}$ & $7.39 \mathrm{a}$ \\
$\mathrm{T}_{3}$ & $31.27 \mathrm{a}$ & $30.31 \mathrm{a}$ & $4.29 \mathrm{a}$ & $4.27 \mathrm{a}$ & $12.52 \mathrm{a}$ & $11.59 \mathrm{a}$ & $7.05 \mathrm{a}$ & $7.35 \mathrm{a}$ \\
$\mathrm{T}_{4}$ & $32.28 \mathrm{a}$ & $31.76 \mathrm{a}$ & $4.38 \mathrm{a}$ & $4.24 \mathrm{a}$ & $12.22 \mathrm{a}$ & $12.62 \mathrm{a}$ & $7.04 \mathrm{a}$ & $7.37 \mathrm{a}$ \\
$\mathrm{T}_{5}$ & $30.7 \mathrm{a}$ & $29.12 \mathrm{a}$ & $4.08 \mathrm{a}$ & $4.50 \mathrm{a}$ & $13.6 \mathrm{a}$ & $12.95 \mathrm{a}$ & $7.29 \mathrm{a}$ & $6.95 \mathrm{a}$ \\
$\mathrm{T}_{6}$ & $31.1 \mathrm{a}$ & $30.37 \mathrm{a}$ & $4.05 \mathrm{a}$ & $4.78 \mathrm{a}$ & $13.15 \mathrm{a}$ & $14.67 \mathrm{a}$ & $7.54 \mathrm{a}$ & $7.73 \mathrm{a}$ \\
$\mathrm{T}_{7}$ & 31.92 & $30.31 \mathrm{a}$ & $4.07 \mathrm{a}$ & $4.35 \mathrm{a}$ & $13.3 \mathrm{a}$ & $11.72 \mathrm{a}$ & $7.68 \mathrm{a}$ & $7.68 \mathrm{a}$ \\
$\mathrm{HSD}(p \leq 0.05)$ & $\mathrm{NS}$ & $\mathrm{NS}$ & $\mathrm{NS}$ & $\mathrm{NS}$ & $\mathrm{NS}$ & $\mathrm{NS}$ & $\mathrm{NS}$ & $\mathrm{NS}$ \\
\hline
\end{tabular}

Means sharing similar letter are not significantly different according to HSD test $(P \leq 0.05)$. NS $=$ Not significant. $\mathrm{T} 1=$ Control, $\mathrm{T} 2=$ Traditional Pruning, $\mathrm{T} 3=$ pruning $10 \% \mathrm{~T} 4=$ Pruning $20 \%$, T5 $=$ Neem oil $1.5 \%, \mathrm{~T} 6=$ Lemongrass oil $1.5 \%, \mathrm{~T} 7=$ Bifenthrin $2 \mathrm{ml} / \mathrm{L}$

Table 4. Effect of biopesticides and tree pruning on biochemical fruit quality during 2016

\begin{tabular}{c|c|c|c|c}
\hline \multicolumn{5}{c}{ Fruit biochemical quality } \\
\hline Treatments & $\begin{array}{c}\text { Vitamin C } \\
(\mathbf{m g} / \mathbf{1 0 0 g})\end{array}$ & $\mathbf{p H}$ & $\mathbf{T S S} / \mathbf{T A}$ & $\begin{array}{c}\text { Total sugars } \\
(\boldsymbol{\%})\end{array}$ \\
\hline $\mathrm{T}_{1}$ & $30.7 \mathrm{a}$ & $4.21 \mathrm{a}$ & $11.01 \mathrm{a}$ & $7.45 \mathrm{a}$ \\
$\mathrm{T}_{2}$ & $28.84 \mathrm{a}$ & $4.23 \mathrm{a}$ & $11.91 \mathrm{a}$ & $7.7 \mathrm{a}$ \\
$\mathrm{T}_{3}$ & $31.95 \mathrm{a}$ & $4.25 \mathrm{a}$ & $12.42 \mathrm{a}$ & $7.68 \mathrm{a}$ \\
$\mathrm{T}_{4}$ & $29.44 \mathrm{a}$ & $4.24 \mathrm{a}$ & $11.18 \mathrm{a}$ & $7.54 \mathrm{a}$ \\
$\mathrm{HSD}(\mathrm{p} \leq 0.05)$ & $\mathrm{NS}$ & $\mathrm{NS}$ & $\mathrm{NS}$ & $\mathrm{NS}$ \\
\hline
\end{tabular}

Means sharing similar letter are not significantly different according to HSD test $(P \leq 0.05)$. NS $=$ Not significant. $\mathrm{T}_{1}=$ Control, $\mathrm{T}_{2}=$ Pruning $10 \%+$ Neem oil $1.5 \%, \mathrm{~T}_{3}=$ Pruning $20 \%+$ Neem oil $1.5 \%$, $\mathrm{T}_{4}=$ Bifenthrin $2 \mathrm{ml} / \mathrm{L}$

\section{Conclusion}

Study witnessed that biopesticides coupled with improved tree pruning at $20 \%$ significantly improved fruit cosmetic quality meanwhile other quality aspects of Kinnow mandarin in comparison with synthetic insecticides. Although pruning at $10 \%$ put more significant impact on fruit size and weight but pruning at $20 \%$ resulted in better fruit cosmetic quality which will ultimately resulted in better pack out. It is need of the hour to screen out more available plant based biopesticides and to establish lowcost technology for its manufacturing and commercialization on large scale. Similarly, 
tree pruning should also be tested with other biopesticides and cultural practices like fruit thinning. These environmentally safe practices could be adopted by replacing hazardous synthetic pesticides to boost up blemish free citrus production without deteriorating internal fruit quality.

Acknowledgments. It is an honor to express deep sense of gratitude and thankfulness to my exsupervisor, Prof. Dr. Nadeem Akhtar Abbasi (Late), Pro-Vice Chancellor, PMAS-AAUR, under whose dynamic and inspiring guidance as well as sympathetic attitude, I started my research work. I am also very much thankful to Roshan Enterprises, Sargodha, leading citrus producers and exporters of Pakistan, for providing citrus orchard to conduct research trials.

\section{REFERENCES}

[1] Ahmad, S., Chatha, Z. A., Nasir, M. A., Aziz, A., Virk, N. A., Khan, A. R. (2006): Effect of pruning on the yield and quality of Kinnow fruit. - Journal of Agriculture \& Social Sciences 2(1): 51-53.

[2] Ahmed, M. (2005): Nature and extent of fruit blemishes in Kinnow mandarin. - M.Sc Research Thesis, Uni. Agri. Faisalabad, Pakistan.

[3] Arshad, M., Ullah, M. I., Afzal, M., Iftikhar, Y., Khalid, S., Hussain, Z. (2019): Evaluation of synthetic insecticides and essential oils for the management of Phyllocnistis citrella Stainton (Lepidoptera: Gracillariidae). - Pakistan Journal of Zoology 51(3): 10531058.

[4] Chaparro, J. X. (2004): Breeding a Red-Fleshed Mandarine (Candidate Gene Analysis). Citrus Research Board, Annual Report, Horticultural Sciences, University of Florida, Gainesville.

[5] Chaudhary, S., Kanwar, R. K., Sehgal, A., Cahill, D. M., Barrow, C. J., Sehgal, R. (2017): Progress on Azadirachta indica based biopesticides in replacing synthetic toxic pesticides. - Frontiers in Plant Science 8: 610.

[6] Dandekar, A. M. (2004): Improving Peel Quality of California Citrus Fruit. - Citrus Research Board, Annual Report, Horticultural Sciences, University of Florida, Gainesville.

[7] Dayan, F. E., Cantrell, C. L., Duke, S. O. (2009): Natural products in crop protection. Bioorganic \& Medicinal Chemistry 17: 4022-4034.

[8] Deka, S., Sehgal, M., Kakoti, R. K., Barbora, A. C. (2018): Module analysis for insect pest management of khasi mandarin (Citrus reticulata Blanco) under climatic conditions of north-eastern India. - Journal of Entomology and Zoology Studies 6(4): 857-861.

[9] Dick, J. (2007): Pruning Citrus Trees. - Department of Agriculture, Western Australia.

[10] Dimetry, N. Z., Ibrahim, S. S., Metwally, H. M., El-Behery, H. (2018): Fumigant potential of some essential oils against the cowpea beetle "callosobruchus maculatus" under laboratory conditions. - Bioscience Research 15(3): 2364-2373.

[11] Fake, C. (2012): Pruning citrus. - University California Cooperative Extension, California. http://www. ucanr.edu/sites/ placernevadasmallfarms/files/134946. pdf (last accessed on 22 March 2018).

[12] Fatima, S., Iram, S. (2019): Identification of fungal pathotypes associated with skin disorders of Citrus reticulata Blanco through classical and molecular approach. - Pakistan Journal of Agricultural Research 32(1): 95-101.

[13] Hikal, W. M., Baeshen, R. S., Said-Al Ahl, H. A. (2017): Botanical insecticide as simple extractives for pest control. - Cogent Biology 3(1): 1404274.

[14] Hong, J. K., Yang, H. J., Jung, H., Dong, J. Y., Sang, M. K., Jeun, Y. C. (2015): Application of volatile antifungal plant essential oils for controlling pepper fruit anthracnose by Colletotrichum gloeosporioides. - Plant Pathology Journal 31: 269-277. 
[15] Ibitayo, O. O. (2006): Egyptian rural farmers' attitudes and behaviors regarding agricultural pesticides: Implications for pesticide risk communication. - Risk Anal. 26: 989-995.

[16] Khalid, M. S., Malik, A. U., Saleem, B. A., Khan, A. S., Javed, N. (2012): Horticultural mineral oil application and tree canopy management improve cosmetic fruit quality of Kinnow mandarin. - African Journal of Agricultural Research 7(23): 3464-3472.

[17] Khan, A. S., Ahmed, M. J., Singh, Z. (2011): Increased ethylene biosynthesis elevates incidence of chilling injury in cold store "Amber Jewel" Japanese plum (Prunus saliciana Lind L) during fruit ripening. - International Journal of Food Science and Technology 46: 642-650.

[18] Koul, O. (2008): Phytochemicals and insect control: an antifeed ant approach. - Critical Review of Plant Sciences 27: 1-24.

[19] Koul, O., Dhaliwal, G. S., Marwaha, S. S., Arora, J. K. (2003): Future perspectives in biopesticides. - Biopesticides and Pest Management 1: 386-388.

[20] Marini, R. (2014): Physiology of Pruning Fruit Trees. - Communications and Marketing, College of Agriculture and Life Sciences, Virginia Polytechnic Institute and State University.

[21] Morales, P., Davies, F. S. (2000): Pruning and skirting affect canopy microclimate, yields, and fruit quality of 'Orlando' tangelo. - Hortscience 35(1): 30-35.

[22] Pavela, R., Benelli, G. (2016): Essential oils as eco-friendly biopesticides? Challenges and constraints. - Trends in Plant Sciences. DOI: 10.1016/j.tplants.2016. 10.005.

[23] Priestley, C. M., Williamson, E. M., Wafford, K. A., Sattelle, D. B. (2003): Thymol, a constituent of thyme essential oil, is a positive allosteric modulator of human GABA receptors and a homo-oligomeric GABA receptor from Drosophila melanogaster. - Br. Journal of Pharmacology 140: 1363-1372.

[24] Rani, A., Misra, K. K., Rai, R., Singh, O. (2018): Effect of shoot pruning and paclobutrazol on vegetative growth, flowering and yield of lemon (Citrus limon Burm.) cv. pant lemon. - Journal of Pharmacognosy and Phytochemistry 7(1): 2588-2592.

[25] Saleem, B. A., Malik, A. U., Pervez, M. A., Khan, A. S., Khan, M. N. (2008): Spring application of growth regulators affects fruit quality of 'blood red' sweet orange. Pakistan Journal of Botany 40(3): 1013-1023.

[26] Sirohi, A., Tandon, P. (2014): Insecticidal effects of various parts of Azadirachta indica on adults of Aulacophora foveicollis (Lucas) (Coleoptera: Chrysomelidae). - Trends in Biosciences 7: 3947-3949.

[27] Sivakumar, D., Bautista-Baños, S. (2014): A review on the use of essential oils for postharvest decay control and maintenance of fruit quality during storage. - Crop Protection 64: 27-37.

[28] Steel, R. G. D., Torrie, J. H., Dickey, D. (1997): Principles and Procedures of Statistics: A Biometrical Approach. 3rd Ed. - McGraw Hill Book Co. Inc., New York.

[29] Yadav, I. C., Devi, N. L., Syed, J. H., Cheng, Z., Li, J., Zhang, G. (2015): Current status of persistent organic pesticides residues in air, water and soil, and their possible effect on neighboring countries: a comprehensive review of India. - Science of the Total Environment 511: 123-137. 